\title{
Critical analysis of aortic dysmorphism in Marfan Syndrome
}

\author{
SOUZA, R. B. ${ }^{1}$, CASSIANO, L. L. ${ }^{2}$, LIBERATORE, A. M. A. ${ }^{3}$, \\ TEDESCO, R. C. ${ }^{1}$, KOH, I. H. J. ${ }^{3}$, MARTINS, A. M. C. R. P. F. ${ }^{2}$, \\ VRETOS, C. ${ }^{4}$ and ALONSO, L. G. ${ }^{1}$ \\ ${ }^{1}$ Departamento de Morfologia e Genética, Escola Paulista de Medicina - EPM, Universidade Federal de \\ São Paulo - UNIFESP, Rua Botucatu, 740, CEP 04023-900, São Paulo, SP, Brasil \\ ${ }^{2}$ Laboratório Interinstitucional de Sanidade em Aquicultura, Avenida Conselheiro Rodrigues Alves, 1252, \\ CEP 04014-002, São Paulo, SP, Brasil \\ ${ }^{3}$ Departamento de Cirurgia, Escola Paulista de Medicina - EPM, Universidade Federal de São Paulo - UNIFESP, \\ Rua Pedro de Toledo, 669, 10 andar, CEP 04039-032, São Paulo, SP, Brasil \\ ${ }^{4}$ Universidade Anhembi Morumbi, Rua Dr. Almeida Lima, 1134, CEP 03164-000, São Paulo, SP, Brasil \\ *E-mail: rodrigo.barbosa72@yahoo.com
}

\begin{abstract}
Introduction: Marfan syndrome (OMIM \#154700) was described for the first time in 1896 by Antoine Bernard-Jean Marfan. It is characterized by its autosomal dominant inheritance pattern, affects 1:5000 of those born alive, and involves the gene that codifies the structural protein fribrillin-1. Fibrillin-1 is critical for the formation of the elastic system backbone and for the negative regulation of the cytokine transforming growth factor beta 1 (TGF- $\beta 1$ ). In the syndrome this fibrillar component causes the degeneration of the fibers of the elastic system, which no longer sequesters matrix TGF- $\beta$, causing disorganization of the collagen fibers and vascular smooth muscles. The disease affects mainly the cardiovascular system, cardiovascular problems being the main cause of death. This is because arteries have large amounts of elastic fibers that rupture in an adverse process, causing mainly dissections and aneurisms, which have been better clarified in experimental studies with mice. Objective: The objective of this study was to conduct an etiopathogenic and molecular review to describe the advances in the understanding of blood vessel dysmorphism in the syndrome, especially of the aorta. Materials and Methods: For this purpose the literature of the last 35 years was extensively reviewed. Conclusion: The origin of the aortic dysmorphism in the syndrome stems from a number of events that begin with the mutation of the gene fibrillin-1, causing fragmentation of the aortic elastic fibers. Excess cytokine TGF- $\beta$ increases the amount of metalloproteinases and of vascular smooth muscle cell apoptosis, leading to matrix remodeling and increasing the susceptibility of the vessel to an aneurysm or dissecting process.
\end{abstract}

Keywords: Marfan syndrome, arterial wall, morphology, extracellular matrix, aneurysm, dissecting aneurysm.

\section{Introduction}

Marfan syndrome (OMIM \#154700) is an autosomal dominant inheritance condition described in 1896 by the French pediatrician Antoine Bernard-Jean Marfan. The syndrome is linked to the gene fibrillin-1 (FBNI) that codifies the protein fibrillin-1 (OMIM *134797), whose locus is located at 15q21.1. Mutations of the gene $F B N 1$ were associated with the disease in 1991. Accurate molecular diagnosis is challenging because of the more than 1500 described mutations. The proteins fibrillin- 1 and fibrillin- 2 form the backbone of the elastic system for elastin deposition and by extension, of the elastic fibers. Abnormalities of the gene FBN1 lead to structural changes in the protein fibrillin- 1 , causing degeneration of the elastic system and disorganization of the collagen fibers and vascular smooth muscle of the aorta. Aortic microfibrils (fibrillin-1 and fibrillin-2) regulate the expression of the transforming growth factor beta (TGF- $\beta$ ) and so mutations of the gene $F B N 1$ increase the amount of circulating and tissue cytokine, compromising vascular smooth muscle and the integrity of the extracellular matrix.

Since arteries have large amounts of elastic fibers, the cardiovascular system is affected in more than $90 \%$ of the patients, causing mainly aortic dilation, aneurysm, and dissection. Given the challenge of understanding the intrinsic mechanisms of the disease, studies in experimental models in mice have advanced the understanding of the syndrome's pathophysiology and improved the available treatments.

\section{Materials and Methods}

A systematic search of the literature published between 1980 and 2014 was conducted in the following electronic databases: Web of Science, MedLine, LILACS, Scielo, and Oxford Journals, in addition to a manual search in book chapters, theses, and references of the selected studies in English, Spanish, and Portuguese using the keywords: "síndrome de Marfan" [Marfan syndrome], "morfologia" [morphology], "matriz extracelular" [extracellular matrix], "aneurisma" [aneurysm], and "aneurisma dissecante" [aneurysm, dissecting].

The exclusion criteria were: repeated studies in the various databases, studies without the keywords in the title, and studies with the keywords in the title but without the subject of interest in the abstract. 


\section{Results and Discussion}

After the original description of the disease made by Antonie Bernard-Jean Marfan, other explanations of the condition emerged, such as one provided by Weve, who believed that the disease was caused by a disorder of the mesodermal structures (BEIGHTON, 1993). After Weve's theory, researchers looked for the etiopathology of the syndrome, assuming the disorder was caused by collagen fibers, and later, by elastin (BYERS, SIEGEL, PETERSON et al., 1981; BORRESEN, BAMFORTH, TSIPOURAS et al., 1985; TSIPOURAS, BORRESEN, BAMFORTH et al., 1986; AHTI, PALOTIE, KAITILA et al., 1987; KAINULAINEN, SAVOLAINEN, PALOTIE et al., 1990; TSIPOURAS, SARFARAZI, DEVI et al., 1991). With the discovery of the microfibril fibrillin-1 in 1986 (SAKAI, KEENE and ENGVALL, 1986) Hollister, Godfrey and Sakay (1990) Lee, Godfrey, Vitale et al. (1991), Magenis, Maslen, Smith et al. (1991), and Dietz, Pyeritz, Hall et al. (1991b) found an association between the syndrome and the gene FBNI using in situ hybridization techniques. In that same year Dietz, Cutting, Pyeritz et al. (1991a) described the first mutation in patients with the syndrome, and in 1993 Pereira, D'Alessio, Ramirez et al. concluded the sequencing of the gene.

The genomic organization of the gene FBNI (locus in 15q21.1) was elucidated by Pereira, D'Alessio, Ramirez et al. (1993) and Corson, Chalberg, Dietz et al. (1993), who divided the gene with $200 \mathrm{~Kb}$ (BIERY, ELDADAH, MOORE et al., 1999) into 65 exons, with an mRNA containing 9663 nucleotides.

The codified protein, fibrillin- 1 , is a calcium-binding glycoprotein rich in cysteine, with intra- and interstrand disulfide bonds (HANDFORD, 2000) discovered in 1986 by Sakai, Keene and Engvall in human fibroblast cultures. Using electron microscope and in situ hybridization techniques, fibrillin-1 was identified in the extracellular matrix of the skin, lungs, kidneys, vascular compartment, cartilage, tendons, muscles, cornea, and zonule of Zinn (SAKAI, KEENE, GLANVILLE et al., 1991).

Pereira, D'Alessio, Ramirez et al. (1993) and Corson, Chalberg, Dietz et al. (1993) divided the protein into five domains: A, B, C, D, and E. Domain A contains exon 1, the cleavage site; domain $\mathrm{B}$ has exons 2-10; domain $\mathrm{C}$ has exon 10 , rich in proline; domain $\mathrm{D}$, the largest domain, has exons 1 1-63; and domain E has exons 64 and 65 (ROBINSON and GODFREY, 2000; ONLINE..., 2014).

Domains B-D consist of repeated motifs (specific amino acid sequence characteristic of a biochemical function) separated into three groups. The first motif is the epidermal growth factor-like motif (EGF) that repeats 47 times in this segment, and in 43 of those times, the molecule presents a calcium-binding variation, the calcium binding EGF-like motif. The second motif is the latent transforming binding protein (LTBP) with eight cysteine residues, analogous to that of the molecule latent transforming growth factor $\beta 1$ (LTGF $\beta 1$ ). The third motif is a fusion between parts of the EGF motif and the LTBP motif, forming the fibmotif (Figure 1) (PEREIRA, D'ALESSIO, RAMIREZ et al., 1993; CORSON, CHALBERG, DIETZ et al., 1993; ASHWORTH, KIELTY and McLEOD, 2000; LIMA, SANTOS, FERNANDES et al., 2010).

Fibrillin- 1 is a critical glycoprotein for the formation of the elastic fiber system (SHERRATT, WESS, BALDOCK et al., 2001 ) and for the negative control of the cytokine transforming growth factor $\beta$ I (TGF- $\beta 1$ ) (Figure 1) (SENGLE, TSUTSUI, KEENE et al., 2012; BYERS, 2004; KIELTY, 2006).

In the formation of the system of elastic fibers, fibrillin-1 interacts with other fibrillar components such as fibrillin-2, fibronectin-4, fibulin-8, and with the MAGP (glycoproteins associated with microfibril) (ADAMTS10, ADAMTSL, and

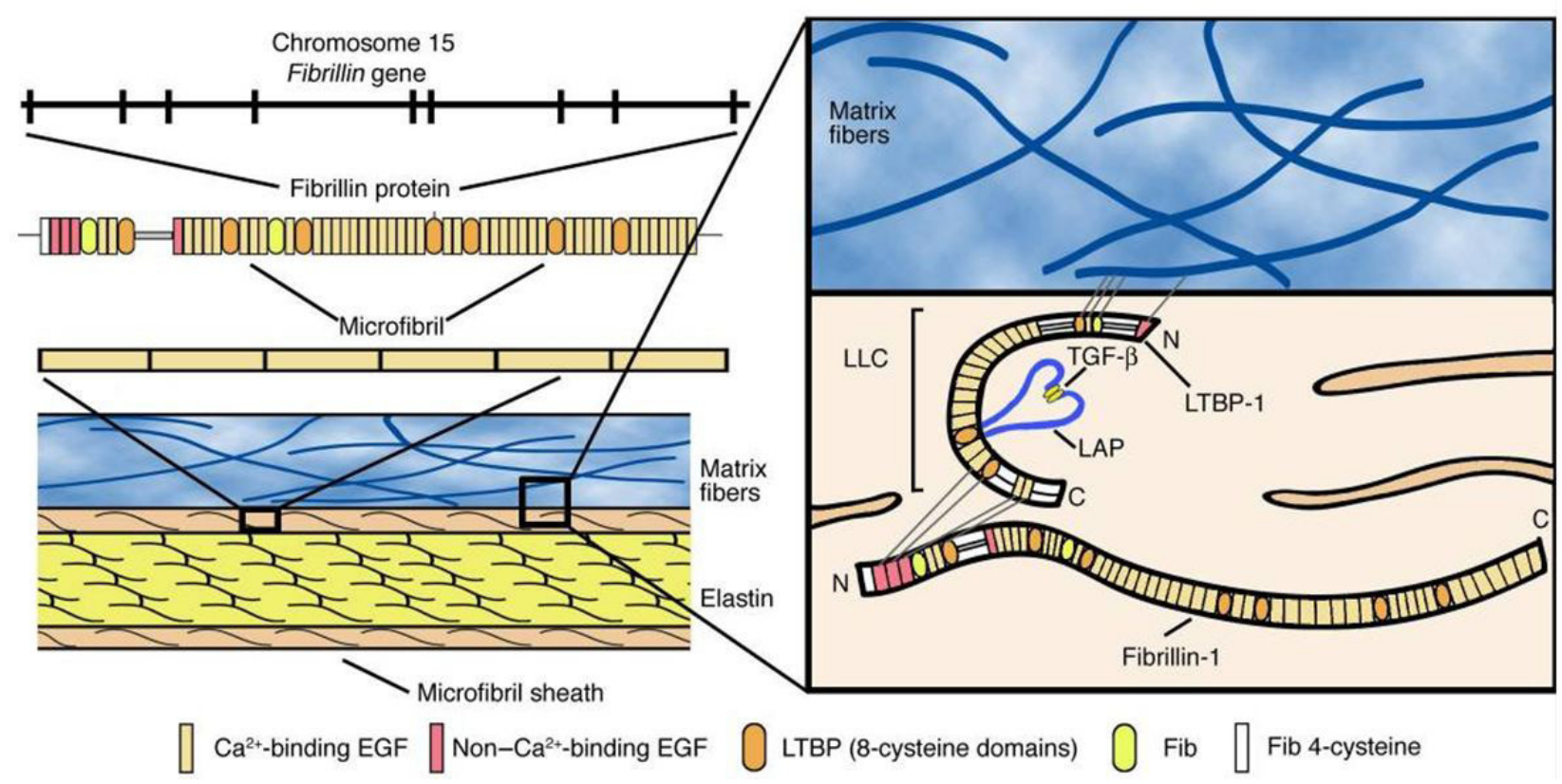

Figure 1. Extracted from Byers (2004). The protein fibrillin-1 is codified from the mRNA transcribed from the gene FBN1 at $15 \mathrm{q} 21.1$. Next, the protein is processed and binds with other fibrillar components forming microfibrils, which in turn interact with elastin, constituting mature elastic fiber. In another segment the image illustrates association between the elastic fiber and the extracellular matrix. Finally, fibrillin-1 is associated with the cytokine TGF- $\beta 1$, and the latter, with the extracellular matrix. 
ADAMTS; KIELTY, SHERRATT and SHUTTLEWORTH, 2002; BALDWIN, SIMPSON, STEER et al., 2013), forming the fibrillar component of elastic fibers. As the tropoelastin molecule interconnects with the fibrillar components, they form arrangements classified into three types of fiber: oxytalan, elaunin, and mature elastic (JUNQUEIRA and CARNEIRO, 2013).

Oxytalan fibers consist of microfibril bundles with a diameter of $10 \mathrm{~nm}$ composed of various glycoproteins, including fibrillin. They are found in the zonule of Zinn in the eyes, in periodontal ligaments, esophageal submucosa, and certain places of the skin, where they connect the elastic system to the basal lamina (FERRAZ DE CARVALHO and KÖNIG JUNIOR, 1982; FERRAZ DE CARVALHO, 1987; INOUE, HARA and SATO, 2012; BALDWIN, SIMPSON, STEER et al., 2013; JUNQUEIRA and CARNEIRO, 2013).

Elaunin fibers have a disorganized deposit of tropoelastin between the microfibrils (oxytalan fibers). They are found around the sweat glands, in the skin, esophageal submucosa, and juxtacanalicular tissue of Schlemm's canal (HANN and FAUTSCH, 2011; BALDWIN, SIMPSON, STEER et al., 2013; JUNQUEIRA and CARNEIRO, 2013).

In mature elastic fibers, tropoelastin builds up until it fills the entire bundle of microfibrils. They are the most numerous fibers of the elastic system, found mainly in blood vessels (BALDWIN, SIMPSON, STEER et al., 2013; JUNQUEIRA and CARNEIRO, 2013).

Given the LTBP motifs, the cytokine TGF- $\beta 1$ anchors on fibrillin- 1 , which then controls its bioavailability keeping it latent (LTGF- $\beta 1$ ) (KAARTINEN and WARBOURTON, 2003; BYERS, 2004) (Figure 1.). Mutations in the gene fibrillin-1 change the formation of the elastic fiber system, making them fragile and fragmented (ROBINSON and GODFREY, 2000). There is also a likely change in the molecule that prevents the cytokine TGF- $\beta 1$ from binding to fibrillin- 1 , leaving too much of it active in the tissue and circulating blood (NEPTUNE, FRISCHMEYER, ARKING et al., 2003; MATT, SCHOENHOFF, HABASHI et al., 2009).

The cytokine TGF- $\beta$ is involved in many physiological phenomena (PARDALI and DIJKE, 2012; DOBACZEWSKI, CHEN and FRANGOGIANNIS, 2011). It is also a strong activator of mast cells, metalloproteinases (MMP), fibroblast contractibility, and apoptotic process of the vascular smooth muscle cells (HANS, FENG, NAURA et al., 2011; HEISSIG, RAFII, AKIYAMA et al., 2005; CHUNG, YUENG, SANDOR et al., 2007; MARGULIS, NOCKA, WOOD et al., 2009).

The frailty of the elastic fibers and the excess cytokines in the extracellular matrix aggravate the disease phenotype. The cardiovascular system is affected in more than $90 \%$ of the patients, since arteries contain a large amount of elastic fibers (PYERITZ, 2000; STUART and WILLIANS, 2007; HOLM, HABASHI, DOYLE et al., 2011; CHIU, WU, CHEN et al., 2014).

The aorta is an elastic artery divided into three structural components: tunica intima, tunica media, and tunica externa. The tunica intima is rich in thick elastic fibers. The tunica media contains perforated elastic laminae organized concentrically. The smooth muscle cells, collagen fibers, proteoglycans, and glycoproteins are found between these elastic fibers. The tunica externa contains collagen fibers surrounding the vessel, with small vessels in their periphery (Vaso vasorum) (JUNQUEIRA and CARNEIRO, 2013).
Stuart and Willians (2007), found that $60 \%$ to $80 \%$ of the patients with Marfan syndrome presented aortic dilation, later developing dissection; in $76 \%$ of the cases, the pulmonary artery was also dilated, but rarely dissected; $52 \%-68 \%$ of the cases presented primary prolapse of the mitral valve that later evolved into arrhythmias; $80 \%-100 \%$ of the cases experienced dilation in the descending aorta after dissection; $4 \%$ of the cases presented prolapse of the tricuspid valve; $20 \%-30 \%$ of these evolved to arrhythmias; less than $1 \%$ presented aneurysm in the coronary arteries; $4 \%$ presented atrial septal defect; and $36 \%$ presented left ventricular dysfunction (children). Recent studies show that the greatest concern with Marfan syndrome patients is still aortic dilation and dissection because of its fatality (TSAI, LIN, HSU et al., 2009; JONDEAU, DETAINT, TUBACH et al., 2012; CHIU, WU, CHEN et al., 2014).

Marshall, Carlson, O'Malley et al. (2013), found circulating fibrillin-1, showing that the elastic fibers of the arteries are not only fragmented but also have a fragile backbone, losing its main component and facilitating the establishment of a dissecting process.

Excess TGF- $\beta 1$ promotes a positive regulation of metalloproteinases (MMP), whose function is to degrade matrix elements. In the syndrome activated MMP deteriorate the mechanical properties of the aorta, decreases its contractility, increases apoptosis, and increases osteopontin in the smooth muscle cells, making the vessel susceptible to aneurysms, dissections, and even rupture (CHUNG, YUENG, SANDOR et al., 2007; HANS, FENG, NAURA et al., 2011; HOLM, HABASHI, DOYLE et al., 2011; HABASHI, DOYLE, HOLM et al., 2011; BALDWIN, SIMPSON, STEER et al., 2013).

According to CHUNG, YUENG, and SANDOR et al., 2007, contraction of the vascular smooth muscle cells regulates the resistance to traction of the aortic wall. Excess TGF- $\beta 1$ reduces $\alpha S M$-actin expression, which reduces vessel integrity and $\alpha \mathrm{SM}$-actin function, leaving the aorta even more susceptible to aneurysms and dissections associated with the syndrome (CHUNG, YUENG, SANDOR et al., 2007; SYYONG, CHUNG, YANG et al., 2009; HOLM, HABASHI, DOYLE et al., 2011; BALDWIN, SIMPSON, STEER et al., 2013).

Given the complexity of Marfan syndrome, experimental models in mice were necessary (HAMILTON and YU, 2012). The first experimental models were $M g \Delta$ and MgR (PEREIRA, ANDRIKOPOULOS, TIAN et al., 1997; PEREIRA, LEE, GAYRAUD et al., 1999), both with low gene expression, thereby characterizing the syndrome only in homozygosis (PEREIRA, LEE, GAYRAUD et al., 1999; JUDGE, BIERY, KEENE et al., 2004).

Later researchers found that these models did not provide reliable methods to test the interference of the negative domain of the mutant allele (JUDGE, BIERY, KEENE et al., 2004). Hence, in order to perfect the experimental models, Judge, Biery, Keene et al. (2004), discussed the formation of the experimental model Cl663R, which substitutes one of the six cysteine residues by a motif calcium-binding epidermal growth factor like (cbEGF-like). This mutation is very common in humans with Marfan syndrome. However, the experimental model does not present the cardiovascular phenotype, which is the greatest concern in practice. Thus, researchers created the murine $\mathrm{C} 1039 \mathrm{G}$ model, characterized by the substitution of cysteine by glycine in the residue 1039 of the EGF motif of the gene (HABASHI, JUDGE, HOLM et al., 2006). 
This model has the backbone and cardiovascular phenotypes commonly found in the affected patients (LIMA, SANTOS, FERNANDES et al., 2010).

The most recent model is the $\operatorname{Mg} \Delta^{\text {LoxPneo }}$, a variant of the $\mathrm{mg} \Delta$ model with deletion of the resistant neomycin cassette. Consequently, the fibrillin- 1 gene presents a deletion between exons 19-24 (LIMA, SANTOS, FERNANDES et al., 2010). This new model manifests the negative domain of the disease, phenotypic variability with backbone changes, and chronic pulmonary inflammation.

Based on experimental models, the pathophysiological mechanisms of the disease were better clarified, which can improve treatments and surgical techniques, increasing patient longevity and quality of life.

\section{Final Considerations}

The origin of the aortic dysmorphism was much better clarified by studies with experimental murine models. A priori, it stems from a number of events that begin with the mutation of the gene that codifies the protein fibrillin-1, causing fragmentation of the aortic elastic fibers. Unbalance of the cytokine TGF- $\beta 1$ occurs along with this event, increasing the amount of metalloproteinases and vascular smooth muscle apoptosis, making the vessel susceptible to aneurysms and dissections. Therefore, we notice that despite the monogenic nature of the anomaly, hence a the genetic etiopathogenesis, many other subsequent situations occur at the expense of incorrect secondary events in the intracellular cascade mediated by fibrillin-1, culminating in the various morphological anomalies, especially in the cardiovascular compartment.

\section{References}

AHTI, H., PALOTIE, A., KAITILA, I. and PELTONEN, L. RFLPstudies in Finnish Marfan families and polymorphism of type I collagen gene in the Finnish population. Cytogenetics and Cell Genetics, 1987, vol. 46 , p. 568 .

ASHWORTH, JL., KIELTY, CM. and MCLEOD, D. Fibrilin and the eye. The British Journal of Ophthalmology, 2000, vol. 84, n. 11, p. 1312-1317. PMid:11049961. http://dx.doi.org/10.1136/ bjo.84.11.1312.

BALDWIN, AK., SIMPSON, A., STEER, R., CAIN, SA. and KIELTY, CM. Elastic fiber in health and disease. Expert Reviews in Molecular Medicine, 2013, vol. 15, n. e8, p. 1-30. PMid:23962539.

BEIGHTON, P. McKusick's heritable disorders of connective tissue. Saint Louis: Mosby-Year Book, 1993. 748 p

BIERY, NJ., ELDADAH, ZA., MOORE, CS., STETTEN, G., SPENCER, F. and DIETZ, HC. Revised genomic organization of FBNl and significance for regulated gene expression. Genomics, 1999, vol. 56, n. 1, p. 70-77. PMid:10036187. http://dx.doi. org/10.1006/geno.1998.5697.

BORRESEN, AL., BAMFORTH, S., TSIPOURAS, P. and BERG, K. Studies of RFLPs at the pro-alpha-2(I) collagen locus exclude close linkage to Marfan syndrome. Cytogenetics and Cell Genetics, 1985 , vol. 40 , p. 585 .

BYERS, PH. Determination of the molecular basis of Marfan syndrome: a growth industry. The Journal of Clinical Investigation, 2004, vol. 114, n. 2, p. 161-163. PMid:15254580. http://dx.doi. org/10.1172/JCI200422399.

BYERS, PH., SIEGEL, RC., PETERSON, KE., ROWE, DW., HOLBROOK, KA., SMITH, LT., CHANG, YH. and FU, JCC. Marfan syndrome: abnormal alpha- 2 chain in type I collagen. Proceedings of the Naional of Academy of Science, 1981, vol. 78, n. 12, p. 7745-7749. PMid:6950413. http://dx.doi.org/10.1073/pnas.78.12.7745.

CHIU, HH., WU, MH., CHEN, HC., KAO, FY. and HUANG, SK. Epidemiological profile of Marfan syndrome in general population: a national database study. Mayo Clinic Proceedings, 2014, vol. 89, n. 14, p. 34-42. PMid:24388020. http://dx.doi.org/10.1016/j. mayocp.2013.08.022.

CHUNG, AWY., YUENG, KA., SANDOR, GGS., JUDGE, DP., DIETZ, HC. and BREEMEN, C. Loss of elastic fiber integrity and reduction os vascular smooth muscle contraction resulting from the upregulated activities of matriz metalloproteinase-2 and -9 in the thoracic aortic aneurysm in Marfan syndrome. Circulation Research, 2007, vol. 101, n. 5, p. 512-522. PMid:17641224. http://dx.doi. org/10.1161/CIRCRESAHA.107.157776.

CORSON, GM., CHALBERG, SC., DIETZ, HC., CHARBONNEAU, NL. and SAKAI, LY. Fibrillin binds calcium and is coded by cDNAs that reveal a multidomain structure and alternatively spliced exons at the 5-prime end. Genomics, 1993, vol. 17, n. 2, p. 476-484. PMid:7691719. http://dx.doi.org/10.1006/geno.1993.1350.

DIETZ, HC., CUTTING, GR., PYERITZ, RE., MASLEN, CL., SAKAI, LY., CORSON, GM., PUFFENBERGER, EG., HAMOSH, A., NANTHAKUMAR, EJ., CURRISTIN, SM., STETTEN, G., MEYERS, DA. and FRANCOMANO, CA. Marfan syndrome caused by a recurrent de novo missense mutation in the fibrillin gene. Nature, 1991a, vol. 352, n. 6333, p. 337-339. PMid:1852208. http://dx.doi. org/10.1038/352337a0.

DIETZ, HC., PYERITZ, RE., HALL, BD., CADLE, RG., HAMOSH, A., SCHWARTZ, J., MEYERS, DA. and FRANCOMANO, CA. The Marfan syndrome locus: confirmation of assignment to chromosome 15 and identification of tightly linked markers at $15 \mathrm{q} 15-\mathrm{q} 21.3$. Genomics, 1991b, vol. 9, n. 2, p. 355-361. PMid:2004786. http:// dx.doi.org/10.1016/0888-7543(91)90264-F.

DOBACZEWSKI, M., CHEN, W. and FRANGOGIANNIS, NG. Transforming growth factor (TGF)- $\beta$ sinaling in cardiac remodeling. Journal of Molecular and Cellular Cardiology, 2011, vol. 51, n. 4, p. 600-606. PMid:21059352. http://dx.doi.org/10.1016/j. yjmcc.2010.10.033.

FERRAZ DE CARVALHO, CA. and KÖNIG JUNIOR, B. Light and electron microscopic study on the oxytalan elaunin andelastic fibers in the inferior segment of the human esophagus. Anatomischer Anzeiger, 1982, vol. 152, n. 2, p. 141-157. PMid:7158796.

FERRAZ DE CARVALHO, CA. The elastic fibre system in the veins of the human lower oesophagus. Acta Anatomica, 1987, vol. 129, n. 1, p. 15-21. PMid:3618093. http://dx.doi.org/10.1159/000146371.

HABASHI, JP., DOYLE, JJ., HOLM, TM., AZIZ, H., SCHOENHOFF, F., BEDJA, D., CHEN, Y., MODIRI, AN., JUDGE, DP. and DIETZ, HC. AngiotensinII type 2 receptor signaling attenuates aortic aneurysm in mice through ERK antagonism. Science, 2011, vol. 332, n. 6027, p. 361-365. PMid:21493863. http://dx.doi. org/10.1126/science.1192152.

HABASHI, JP., JUDGE, DP., HOLM, TM., COHN, RD., LOEYS, BL., COOPER, TK., MYERS, L., KLEIN, EC., LIU, G., CALVI, C., PODOWSKI, M., NEPTUNE, ER., HALUSHKA, MK., BEDJA, D., GABRIELSON, K., RIFKIN, DB., CARTA, L., RAMIREZ, F., HUSO, DL. and DIETZ, HC. Losartan, an ATI antagonist, prevents aortic aneurysm in a mouse model of Marfan syndrome. Science, 2006, vol. 312, n. 5770, p. 117-121. PMid:16601194. http://dx.doi. org/10.1126/science.1124287.

HAMILTON, BA. and YU, BD. Modifier genes and the plasticity genetic networks in mice. PLOS Genetics, 2012, vol. 8, n. 4, p. 1-7. PMid:22511884. http://dx.doi.org/10.1371/journal.pgen.1002644.

HANDFORD, PA. Fibrillin-1, a calcium binding protein of extracellular matrix. Biochimica et Biophysica Acta, 2000, vol. 1498, 
n. 2-3, p. 84-90. PMid:11108952. http://dx.doi.org/10.1016/ S0167-4889(00)00085-9.

HANN, CR. and FAUTSCH, MP. The elastin fiber system between and adjacent to collector channels in the human juxtacalicular tissue. Investigative Ophthalmology \& Visual Science, 2011, vol. 52, n. 1, p. 45-50. PMid:20720231. http://dx.doi.org/10.1167/iovs.10-5620.

HANS, CP., FENG, Y., NAURA, AS., TROXCLAIR, D., ZERFAOUI, M., SIDDIQUI, D., JIHANG, J., KIM, H., KAYE, AD., MATROUGUI, K., LAZARTIGUES, E. and BOULARES, AH. Opposing roles of PARP- 1 in MMP-9 and TIMP-2 expression and mast cell degranulation in dyslipidemic dilated cardiomyopathy. Cardiovascular Pathology, 2011, vol. 20, n. 2, p. 57-68. PMid:20434371. http://dx.doi. org/10.1016/j.carpath.2010.03.007.

HEISSIG, B., RAFII, S., AKIYAMA, H., OHKI, Y., SATO, Y., RAFAEL, T., ZHU, Z., HICKLIN, DJ., OKUMURA, K., OGAWA, H., WERB, Z and HATTORI, K. Low-dose irradiation promotes tissue revascularization trough VEGF release from mast cells and MMP-9mediated progenitor cell mobilization. The Journal of Experimental Medicine, 2005, vol. 19, n. 6, p. 736-750. PMid:16157686.

HOLLISTER, DW., GODFREY, M., SAKAY, LY. and PEYRITZ, RE. Immunohistologic adnormalisties of the microfibrillar-fiber system in the Marfan syndrome. The New England Journal of Medicine, 1990, vol. 323, n. 3, p. 152-159. PMid:2194127. http://dx.doi. org/10.1056/NEJM199007193230303.

HOLM, TM., HABASHI, JP., DOYLE, JJ., BEDJA, D., CHEN, YC., ERP, C., LINDSAY, ME., KIM, D., SCHOENHOFF, F., COHN, DP., LOEYS, BL., THOMAS, CJ., PATNAIK, S., MARUGAN, JJ., JUDGE, DP. and DIETZ, HC. Noncanonical TGF $\beta$ signaling contributes to aortic aneurysm progression in Marfan syndrome Mice. Science, 2011, vol. 332, n. 6027, p. 358-361. PMid:21493862. http://dx.doi.org/10.1126/science.1192149.

INOUE, K., HARA, Y. and SATO, T. Development of the oxytalan fiber system in the rat periodontal ligament evaluated by light-and electron-microscopic analyses. Annals of Anatomy, 2012, vol. 194, n. 5, p. 482-488. PMid:22727934. http://dx.doi.org/10.1016/j. aanat.2012.03.010.

JONDEAU, G., DETAINT, D., TUBACH, F., ARNOUlT, F., MILLERON, O., RAOUX, F., DELORME, G., MIMOUN, L., KRAPF, L., HAMROUN, D., BEROUD, C., ROY, C., VAHANIAN, A. and BOILEAU, C. Aortic event rate in the Marfan population: a cohort study. Circulation Research, 2012, vol. 125, n. 2, p. 226-232. PMid:22133496. http://dx.doi.org/10.1161/ CIRCULATIONAHA.111.054676.

JUDGE, DP., BIERY, NJ., KEENE, DR., GEUBTNER, J., MYERS, L., HUSO, DL., SAKAI, LY. and DIETZ, HC. Evidence for a critical contribution of haploinsufficiency in the complex pathogenesis of Marfan syndrome. The Journal of Clinical Investigation, 2004, vol. 114, n. 2, p. 172-181. PMid:15254584. http://dx.doi.org/10.1172/ JCI200420641.

JUNQUEIRA, LCU. and CARNEIRO, J. Histologia Básica. Rio de Janeiro: Guanabara Koogan, 2013. 556 p.

KAARTINEN, V. and WARBOURTON, D. Fibrillin controls TGF- $\beta$ activation. Nature genetics, 2003, vol. 33, p. 331-332.

KAINULAINEN, K., SAVOLAINEN, A., PALOTIE, A., KAITILA, I., ROSENBLOOM, J. and PELTONEN, L. Marfan syndrome: exclusion of genetic linkage to five genes coding for connective tissue components in the long arm of chromosome 2. Human Genetics, 1990, vol. 84, n. 3, p. 233-236. PMid:1968032. http://dx.doi. org/10.1007/BF00200565.

KIELTY, CM. Elastic fibres in heaslth and disease. Expert Reviews in Molecular Medicine, 2006, vol. 8, n. 19, p. 1-23. PMid:16893474. http://dx.doi.org/10.1017/S146239940600007X.
KIELTY, CM., SHERRATT, MJ. and SHUTTLEWORTH, CA. Elastic fibres. Journal of Cell Science, 2002, vol. 115, n. Pt 14, p. 2817-2828. PMid:12082143.

LEE, B., GODFREY, M., VITALE, E., HORI, H., MATTEI, MG., SARFARAZI, M., TSIPOURAS, P., RAMIREZ, F. and HOLLISTER, DW. Linkage of Marfan syndrome and a phenotypically related disorder to two different fibrillin genes. Nature, 1991, vol. 352, n. 6333, p. 330-334. PMid:1852206. http://dx.doi.org/10.1038/352330a0.

LIMA, BL., SANTOS, EJC., FERNANDES, GR., MERKEL, C., MELLO, MRB., GOMES, JPA., SOUKOYAN, M., KERKIS, A., MARSSIRONI, SMG., VISINTIN, JA. and PEREIRA, LV. A new mouse model for Marfan syndrome presents phenotypic variability associated with the genetic background and overall levels of FBN-1 expression. PLOS Genetics, 2010, vol. 30, n. 5, p. el4136.

MAGENIS, RE., MASLEN, CL., SMITH, L., ALLEN, L. and SAKAI, LY. Localization of the fibrillin (FBN) gene to chromosome 15, band q21.1. Genomics, 1991, vol. 11, n. 2, p. 346-351. PMid:1769651. http://dx.doi.org/10.1016/0888-7543(91)90142-2.

MARGULIS, A., NOCKA, KH., WOOD, NL., WOLF, SF., GOLDMAN, SJ. and KASAIAN, MT. MMP dependence of fibroblast contraction and collagen production induced by human mast cell activation in a three-dimensional collagen lattice. American Journal of Physiology. Lung Cellular and Molecular Physiology, 2009, vol. 296, n. 2, p. 236-247. PMid:19060229. http://dx.doi.org/10.1152/ ajplung.90462.2008.

MARSHALL, LM., CARLSON, EJ., O'MALLEY, J., SNYDER, CK., CHARBONNEAU, NL., HAYFLICK, SJ., COSELLI, JS., LEMAIRE, SA. and SAKAI, LY. Thoracic aortic aneurysm frequency and dissection are associated with fibrillin-1 fragment concentration in circulation. Circulation Research, 2013, vol. 113, n. 10, p. 1159-1168. PMid:24036495. http://dx.doi.org/10.1161/ CIRCRESAHA.113.301498.

MATT, P., SCHOENHOFF, F., HABASHI, J., HOLM, T., ERP, CV., LOCH, D., CARLSON, OD., GRISWOLD, BF., FU, Q., BACKER, JD., LOEYS, B., HUSO, D., MCDONNELL, NB., EYK, JEV. and DIETZ, HC. Circulating TGF- $\beta$ in Marfan syndrome. Circulation Research, 2009, vol. 120, n. 6, p. 526-532. http://dx.doi. org/10.1161/CIRCULATIONAHA.108.841981.

NEPTUNE, ER., FRISCHMEYER, PA., ARKING, DE., MYERS, L., BUNTON, TE., GAYRAUD, B., RAMIREZ, F., SAKAI, LY. and DIETZ, HC. Dysregulation of TGF-beta activation contributes to pathogenesis in Marfan syndrome. Nature Genetics, 2003, vol. 33, n. 3, p. 407-411. PMid:12598898. http://dx.doi.org/10.1038/ng1116.

ONLINE MENDELIAN INHERITANCE IN MAN - OMIM [online]. Available from: <http://http://www.omim.org>. Access in: 20 Aug. 2014.

PARDALI, E. and DIJKE, PT. TGF $\beta$ signaling and cardiovascular diseases. International Journal of Biological Sciences, 2012, vol. 8, n. 2, p. 195-213. PMid:22253564. http://dx.doi.org/10.7150/ijbs.8.195.

PEREIRA, L., ANDRIKOPOULOS, K., TIAN, J., LEE, SY., KEENE, DR., ONO, R., REINHARDT, DP., SAKAI, LY., BIERY, NJ., BUNTON, T., DIETZ, HC. and RAMIREZ, F. Targetting of the gene encoding fibrillin-1 recapitulates the vascular aspect of Marfan syndrome. Nature Genetics, 1997, vol. 17, n. 2, p. 218-222. PMid:9326947. http://dx.doi.org/10.1038/ng1097-218.

PEREIRA, L., D'ALESSIO, M., RAMIREZ, F., LYNCH, JR., SYKES, B., PANGILINAN, T. and BONADIO, J. Genomic organization of sequence coding for fibrillin, the defective gene product in Marfan syndrome. Human Molecular Genetics, 1993, vol. 2, n. 7, p. 961968. PMid:8364578. http://dx.doi.org/10.1093/hmg/2.7.961.

PEREIRA, L., LEE, SY., GAYRAUD, B., ANDRIKOPOULOS, K., SHAPIRO, SD., BUNTON, T., BIERY, NJ., DIETZ, HC., SAKAI, LY. and RAMIREZ, F. Pathogenetic sequence for aneurysm revealed in mice underexpressing fibrillin-1. Proceedings of the National Academy 
of Sciences of the United States of America, 1999, vol. 96, p. 3819 3823. PMid:10097121.

PYERITZ, RE. The Marfan syndrome. Annual Review of Medicine, 2000, vol. 51, n. 1, p. 481-510. PMid:10774478. http://dx.doi. org/10.1146/annurev.med.51.1.481.

ROBINSON, PN. and GODFREY, M. The molecular genetics of Marfan syndrome and related microfibrillopathies. Journal of Medical Genetics, 2000, vol. 37, n. 1, p. 9-25. PMid:10633129. http://dx.doi. org/10.1136/jmg.37.1.9.

SAKAI, LY., KEENE, DR. and ENGVALL, E. Fibrillin, a new 350$\mathrm{KD}$ glycoprotein, is a component of extracellular microfibrils. The Journal of Cell Biology, 1986, vol. 103, n. 6 Pt 1, p. 2499-2509. PMid:3536967. http://dx.doi.org/10.1083/jcb.103.6.2499.

SAKAI, LY., KEENE, DR., GLANVILLE, RW. and BACHINGER, HP. Purification and partial characterization of fribillin, a cyteine-rich structural component of connective tissue microfibrils. The Journal of Biological Chemistry, 1991, vol. 266, n. 22, p. 14763-14770. PMid:1860873.

SENGLE, G., TSUTSUI, K., KEENE, DR., TUFA, SF., CARLSON, EJ., CHARBONNEAU, NL., ONO, RN., SASAKI, T., WIRTZ, MK., SAMPLES, JR., FESSLER, LI., FESSLER, JH., SEKIGUCHI, K., HAYFLICK, SJ. and SAKAI, LY. Microenvironmental regulation by fibrillin-1. PLOS Genetics, 2012, vol. 8, n. 1, p. e1002425. PMid:22242013. http://dx.doi.org/10.1371/journal.pgen.1002425.

SHERRATT, MJ., WESS, TJ., BALDOCK, C., ASHWORTH, JL., PURSLOW, PP., SHUTTLEWORTH, CA. and KIELTY, CM. Fibrillin-rich microfibrils of the extracellular matrix: ultrastructure and assembey. Micron (Oxford, England), 2001, vol. 32, n. 2, p.
185-200. PMid:10936461. http://dx.doi.org/10.1016/S09684328(99)00082-7.

STUART, AG. and WILLIANS, A. Marfan's syndrome and the heart. Archives of Disease in Childhood, 2007, vol. 92, n. 4, p. 351-356. PMid:17376944. http://dx.doi.org/10.1136/adc.2006.097469.

SYYONG, HT., CHUNG, AWY., YANG, HHC. and BREEMEN, CV. Dysfunction of endothelial and smooth muscle cells in small arteries of mouse model of Marfan syndrome. British Journal of Pharmacology, 2009, vol. 158, n. 6, p. 1597-1608. PMid:19814726. http://dx.doi. org/10.1111/j.1476-5381.2009.00439.x.

TSAI, SH., LIN, YY., HSU, CW., CHEN, YL., LIAO, MT. and $\mathrm{CHU}, \mathrm{SJ}$. The characteristics of acute aortic dissection among young Chinese patients: A comparison between Marfan syndrome and nonMarfan syndrome patients. Yonsei Medical Journal, 2009, vol. 50, n. 2, p. 239-244. PMid:19430557. http://dx.doi.org/10.3349/ ymj.2009.50.2.239.

TSIPOURAS, P., BORRESEN, AL., BAMFORTH, S., HARPER, PS. and BERG, K. Marfan syndrome: exclusion of genetic linkage to the COL1A2 gene. Clinical Genetics, 1986, vol. 30, n. 5, p. 428432. PMid:2879657.

TSIPOURAS, P., SARFARAZI, M., DEVI, A., WEIFFENBACH, B. and BOXER, M. Marfan syndrome is closely linked to a marker on chromosome 15q1.5-q2.1. Proceedings of the National Academy of Sciences of the United States of America, 1991, vol. 88, n. 10, p. 44864488. PMid:2034688. http://dx.doi.org/10.1073/pnas.88.10.4486.

Received September 15, 2016 Accepted March 12, 2017 